\title{
REMOVAL OF FLUORIDE USING NEEM LEAVES BATCH REACTOR: KINETICS AND EQUILIBRIUM STUDIES
}

\author{
TEJ PRATAP SINGH, MAJUMDER CB*
}

\section{Department of Chemical Engineering, IIT Roorkee, Roorkee - 247 667, Uttarakhand, India. Email: cbmajumder@gmail.com}

Received: 13 July 2017, Revised and Accepted: 06 December 2017

\section{ABSTRACT}

Objective: The aim of this paper is to study the fluoride removal efficiency of the neem leaves low-cost biosorbent for defluoridation of sewage wastewater

Methods: For finding the best operating condition for maximum removal of fluoride, batchwise experiments were performed at different contact times and keeping other parameters to be constant such as pH, initial fluoride concentration, and adsorbent dose. Various kinetic models such as intraparticle diffusion model, Bangham's model, and Elovich model had been investigated for determining the suitable adsorption mechanism. The rate of adsorption of fluoride on neem leaves has been determined by pseudo-first-order and pseudo-second-order rate models.

Results: The adsorption kinetics rate and mechanism was best described by the pseudo-second-order model and Bangham's model, respectively. The optimum pH, initial concentration, adsorbent dose, and contact time were found to be 7, $20 \mathrm{mg} / \mathrm{L}, 10 \mathrm{~g} / \mathrm{L}$, and $40 \mathrm{~min}$, respectively, for which there was maximum fluoride removal.

Conclusion: The result obtained from the experiments show that the neem leaves have been proved to be a low-cost biosorbent for the defluoridation of the sewage wastewater and have high fluoride removal efficiency.

Keywords: Batchwise biosorption experiment, Bangham's model, Langmuir Isotherm.

(C) 2018 The Authors. Published by Innovare Academic Sciences Pvt Ltd. This is an open access article under the CC BY license (http://creativecommons. org/licenses/by/4. 0/) DOI: http://dx.doi.org/10.22159/ajpcr.2018.v11i3.14080

\section{INTRODUCTION}

Fluoride $\left(\mathrm{F}^{-}\right)$contamination in groundwater recognized has been one of the serious problems worldwide [1]. Fluoride is classified as one of the contaminants of water for human consumption by the World Health Organization (WHO), in addition to nitrate and arsenic, which causes large-scale health problems [2]. Large fluoride concentrations in the groundwater occur in major parts of the globe [3-12]. Fluoride is widely distributed in the geological environment [13] and generally released into the groundwater by slow dissolution of fluorine-containing rocks [14]. Many minerals, for example, fluorite, biotitic, topaz, and their corresponding host rocks such as basalt, syenite, granite, and shale contain fluoride that can be released into the groundwater [15-17]. The major source of human intake of fluoride is groundwater. Excluding the natural geological sources for fluoride enrichment in groundwater, in different, different industries is also contributing to fluoride pollution to a great extent [18]. The industrial wastewater containing industries which discharge high fluoride concentrations include ceramic and glass production, electroplating, coal-fired power stations, semiconductor manufacturing, brick and iron works, beryllium extraction plants, and aluminum smelters [19]. It is found that 200 million people worldwide rely on drinking water with fluoride concentrations that exceed the WHO guideline of 1.5 $\mathrm{mg} / \mathrm{L}$ [20]. Determined by the concentration and the duration of continuous intake, the impact of fluoride in drinking water can be estimated to humankind. Small amounts in ingested water are usually considered to have a beneficial effect on the rate of occurrence of dental caries, particularly among children [21]. Drinking water has a fluoride in small useful concentration range in relation to human health. On the contrary, excess intake of fluoride leads to many diseases such as arthritis, brittle bones, osteoporosis, cancer, infertility, Alzheimer syndrome, brain damage, and thyroid disorder [22,23]. Fluorosis is a common problem of high fluoride ingestion manifested by mottling of embrittlement and teething mild cases of neurological and bones damage in severe cases [24]. The other effects include interference with DNA synthesis; problems in carbohydrates, lipids, proteins and their metabolism, vitamins, and minerals; gastrointestinal irritation; nervous system-related problems; kidney and brain malfunctioning; and effects of thyroid activity. [26-28]. In the view of toxic effects of fluoride on human health, there is an urgent need to find out an effective and physically strong technology for the removal of excess fluoride from drinking water and industrial wastewater.

Experimental

The neem leaves were used as the low-cost natural biosorbent. These were sourced from IIT Roorkee Campus, Roorkee, India. The neem leaves were dried, crushed, and washed thoroughly with distilled water to remove adhering dirt. They were dried in a hot air oven at $60-90^{\circ} \mathrm{C}$ for $24 \mathrm{~h}$ after which drying material is crushed in jaw crusher and screened in $50 \mu \mathrm{m}$ mesh ASTM.

The prepared stock solution was $100 \mathrm{mg} / \mathrm{L}$ fluoride, by dissolving $0.221 \mathrm{~g}$ of anhydrous sodium fluoride in 1 liter of Millipore water. The test solution of $20 \mathrm{mg} / \mathrm{L}$ fluoride concentration was prepared from stock solution. The selected concentration is the normal fluoride concentration in industrial wastewater. All the experiments were transferred in $250 \mathrm{ml}$ round bottom flasks, with $50 \mathrm{ml}$ test solution at $29 \pm 1^{\circ} \mathrm{C}$ in round bottom flask in horizontal incubator shaker. At the end of desired contact time, the round bottom flask was separated from the shaker. Subsequently, filtered the samples using Whatman no. 42 filter paper and filtrate was analyzed for residual fluoride concentration by SPADNS method, described in the standard method of examination of industrial wastewater and water [28]. 
Spectrophotometric method

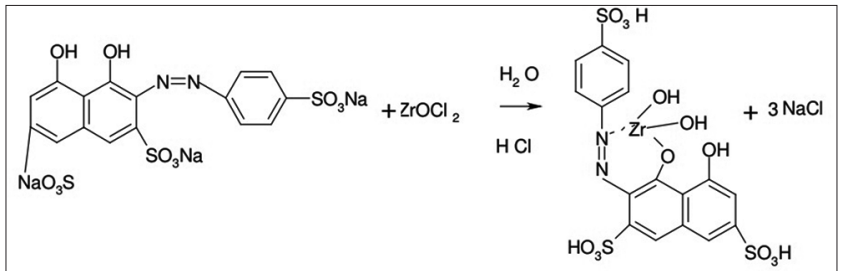

In this technique, a compound of a metal such as aluminum, iron, thorium, zirconium, lanthanum, or cerium reacts with an indicator dye to build a complex of small dissociation constant. This complex reacts with fluoride to give a new complex. Due to the transformation in the configuration of the complex, the surface assimilation spectrum also shifts relative to the spectrum for the fluoride-free reagent solutions. This alteration can be observed using a spectrophotometer. One of the essential dyes employed is trisodium 2-(parasulfophenylazo)-1, 8-dihydroxy-3, and 6-naphthalene disulfonate, generally recognized as SPADNS. Eriochrome cyanine $\mathrm{R}$ is one of the most commonly used dye. The dye reacts with metal ions to give a colored complex. In the SPADNS method, zirconium reacts with SPADNS to build a red colored complex. Fluoride discolors the red color of the complex, and therefore, the alteration in absorbance can be calculated using a spectrophotometer.

Formation of the SPADNS - ZrOCl2 complex

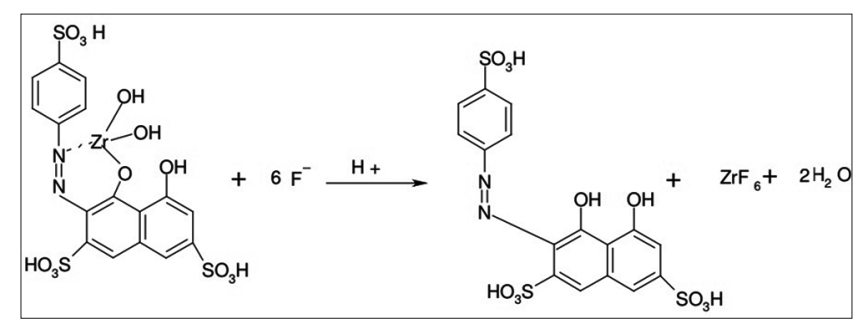

Reaction of the complex with fluoride ions

Recipe for SPADNS solution:

$$
\frac{\text { Mgof fluoride }}{\text { Litre }}=\frac{\mathrm{A}}{\text { Sample }(\mathrm{ml})} \times \frac{\mathrm{B}}{\mathrm{C}}
$$

Where,

A: Represents Fluoride obtained by curve (mg)

B: Represents diluted sample final volume $(\mathrm{mL})$

C: Represents diluted sample volume worn for development of color.

$$
\frac{\text { Mgof fluoride }}{\text { Litre }}=\frac{A_{0}-A_{X}}{A_{0}-A 1}
$$

Where,

$\mathrm{A}_{0}$ : Represents absorbance at zero fluoride concentration

$\mathrm{A}_{1}$ : Represents absorbance at fluoride concentration of $1 \mathrm{mg} / \mathrm{L}$

$\mathrm{A}_{\mathrm{x}}$ : Represents absorbance of sample prepared

\section{RESULTS AND DISCUSSIONS}

\section{Effect of contact time}

A plot between time $t(\mathrm{~min})$ and amount of fluoride adsorbed with time qt $(\mathrm{mg} / \mathrm{g})$ is plotted as shown in Fig. 1. With increase in agitation time, fluoride removal also increases initially, but then gradually approaches a more or less constant value, denoting the attainment of equilibrium. Similar trend was also observed by other researchers during adsorption of fluoride onto protonated chitosan beads [29]. With respect to contact time, neem leaves reached equilibrium after $40 \mathrm{~min}$ which was fixed as their optimum contact times.
Fitness of the kinetic models

The best fit among the kinetic models was assessed by the squared sum of errors (SSE) values. It is assumed that the model which gives the lowest SSE values is the best model for the particular system [30,31]. The SSE values were calculated using the equation:

$$
\mathrm{SSE}=\sum\left(\mathrm{q}_{\text {expt }}^{\mathrm{e}}-\mathrm{q}_{\text {cal }}^{\mathrm{e}}\right)^{2} /\left(\mathrm{q}_{\text {expt }}^{\mathrm{e}}\right)^{2}
$$

Where, $q_{e, e x p t}$ and $q_{e, c a l}$ denotes the experimental sorption capacity of fluoride ( $\mathrm{mg} / \mathrm{g}$ ) at equilibrium time and the corresponding value that was obtained from the kinetic models. SSE values and many kinetic parameters for all the kinetic models were determined and are summarized in Table 1.

\section{Adsorption kinetics}

Five simplified kinetic models, namely, pseudo-second-order, pseudofirst-order, Weber and Morris intraparticle diffusion model, Elovich equations, and Bingham's pore diffusion model have been discussed to identify the rate and kinetics of sorption of fluoride onto neem leaves.

\section{Pseudo-first-order model}

The pseudo-first-order (Lagergren's) rate equation is one of the most widely used rate equation to describe the adsorption of adsorbate from the liquid phase $[32,33]$. The linear form of pseudo-first-order rate expression of Lagergren is given as:

$\log \left(\mathrm{q}_{\mathrm{e}}-\mathrm{q}_{\mathrm{t}}\right)=\log \left(\mathrm{q}_{\mathrm{e}}\right)-\mathrm{k}_{1} \mathrm{t} / 2.303$

Where, qe and qt are the amounts of fluoride adsorbed on adsorbent $(\mathrm{mg} / \mathrm{g})$ at equilibrium and at time $\mathrm{t}(\mathrm{min})$, respectively, and $\mathrm{k} 1$ is the rate constant of pseudo-first-order kinetics. Fig. 2a shows the plots of linearized form of pseudo-first-order kinetic model for the three sorbents. The plots were found linear with good correlation coefficients $(>0.9)$ indicating the applicability of pseudo-first-order model in the present study. The pseudo-first-order rate constant $(\mathrm{k} 1)$ and $\mathrm{q}_{\mathrm{e}}$ (cal.) values were determined for adsorbent from the slope and the intercept of corresponding plot (Fig. 2a) and are listed in Table 1.

\section{Pseudo-second-order model}

The adsorption kinetics were also described as pseudo-second-order process using the following equation [34],

$\mathrm{t} / \mathrm{q}_{\mathrm{t}}=1 / \mathrm{k}_{2} \cdot \mathrm{q}_{\mathrm{e}}{ }^{2}+(1 / \mathrm{qe}) \cdot \mathrm{t}$

Where,

$\mathrm{q}_{\mathrm{e}}$ : Adsorption capacity at equilibrium.

$\mathrm{q}_{\mathrm{t}}$ : Adsorption capacity at time $\mathrm{t}$.

$\mathrm{k}_{2}$ : The rate constant for the pseudo-second-order kinetics.

The plots of $\left(t / q_{t}\right)$ versus time $(t)$ for the adsorbents are shown in Fig. $2 \mathrm{~b}$. The values of $\mathrm{k}_{2}$ and $\mathrm{q}_{\mathrm{e}(\mathrm{call})}$ were calculated for adsorbent from the intercept and slope of the corresponding plot and are compiled in Table 1.

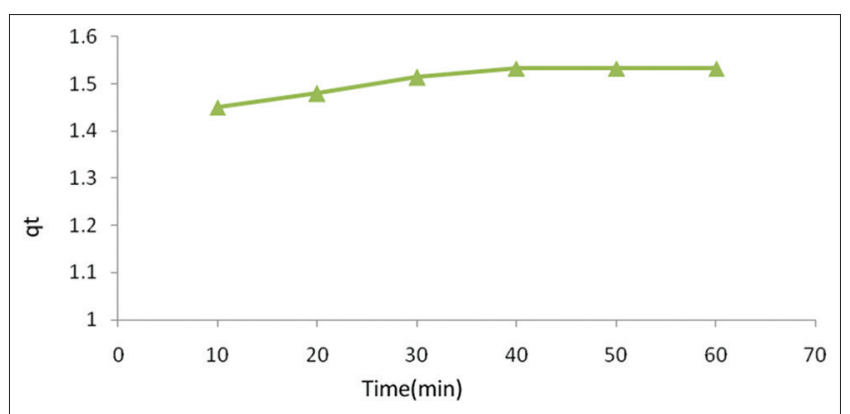

Fig. 1: Effect of contact time on adsorption of fluoride on neem leaves 
Table 1: Table consists of pseudo-second-order, Weber and Morris, pseudo-first-order, Bangham's and Elovich models parameters and calculated $q_{\text {ecal }}$ and experimental $q_{\text {expt }}$ values at $20 \mathrm{mg} / \mathrm{L}$ fluoride concentrations for all five kinetics models stated above

\begin{tabular}{|c|c|c|c|c|c|c|}
\hline \multicolumn{7}{|l|}{ Pseudo-first-order } \\
\hline Name of adsorbent & $\mathrm{k}_{1}\left(\min ^{-1}\right)$ & $\mathrm{q}_{\mathrm{e}(\operatorname{expt})}(\mathrm{mg} / \mathrm{g})$ & $\mathrm{q}_{\mathrm{e}(\mathrm{call})}(\mathrm{mg} / \mathrm{g})$ & \multicolumn{2}{|l|}{$\mathrm{R}^{2}$} & SSE \\
\hline Neem leaves & 0.078 & 1.532 & 0.1999 & \multicolumn{2}{|l|}{0.9418} & 0.756 \\
\hline \multicolumn{7}{|c|}{ Pseudo-second-order } \\
\hline Name of adsorbent & $\mathrm{k}_{2}\left(\mathrm{~min}^{-1}\right)$ & $\mathrm{q}_{\mathrm{e}(\operatorname{expt})}(\mathrm{mg} / \mathrm{g})$ & $\mathrm{q}_{\mathrm{e}(\mathrm{cal})}(\mathrm{mg} / \mathrm{g})$ & \multirow{2}{*}{\multicolumn{2}{|c|}{$\begin{array}{l}\mathrm{R}^{2} \\
0.9999\end{array}$}} & \\
\hline Neem leaves & 0.9903 & 1.532 & 1.54 & & & 0.00003 \\
\hline \multicolumn{7}{|c|}{ Intraparticle diffusion } \\
\hline Name of adsorbent & $\mathrm{k}_{\mathrm{id}}\left(\mathrm{mg} / \mathrm{g} \cdot \mathrm{min}^{-0.5}\right)$ & $\mathrm{q}_{\mathrm{e}(\operatorname{expt})}(\mathrm{mg} / \mathrm{g})$ & $\mathrm{q}_{\mathrm{e}(\text { cal })}(\mathrm{mg} / \mathrm{g})$ & \multicolumn{2}{|l|}{$\mathrm{R}^{2}$} & \\
\hline Neem leaves & 0.027 & 1.532 & 1.3606 & \multicolumn{2}{|l|}{0.9941} & 0.0125 \\
\hline \multicolumn{7}{|l|}{ Pore diffusion } \\
\hline \multirow{2}{*}{$\begin{array}{l}\text { Name of adsorbent } \\
\text { Neem leaves }\end{array}$} & $\mathrm{k}_{0}$ & \multirow{2}{*}{$\begin{array}{l}\mathrm{q}_{\mathrm{e}(\text { expt) }}(\mathrm{mg} / \mathrm{g}) \\
1.532\end{array}$} & \multirow{2}{*}{$\begin{array}{l}\mathrm{q}_{\mathrm{e} \text { (cal) }}(\mathrm{mg} / \mathrm{g}) \\
1.448\end{array}$} & \multirow{2}{*}{$\begin{array}{l}\mathrm{R}^{2} \\
0.842\end{array}$} & \multirow{2}{*}{$\begin{array}{l}\alpha \\
0.001\end{array}$} & \multirow{2}{*}{$\begin{array}{l}\text { SSE } \\
0.03579\end{array}$} \\
\hline & 8.4349 & & & & & \\
\hline \multicolumn{7}{|l|}{ Elovich equation } \\
\hline \multirow{2}{*}{$\begin{array}{l}\text { Name of adsorbent } \\
\text { Neem leaves }\end{array}$} & B & \multirow{2}{*}{$\begin{array}{l}\mathrm{q}_{\mathrm{e}(\operatorname{expt})}(\mathrm{mg} / \mathrm{g}) \\
1.532\end{array}$} & \multirow{2}{*}{$\begin{array}{l}\mathrm{q}_{\mathrm{e} \text { (cal) }}(\mathrm{mg} / \mathrm{g}) \\
0.378\end{array}$} & \multirow{2}{*}{$\begin{array}{l}\mathrm{R}^{2} \\
0.9681\end{array}$} & \multirow{2}{*}{$\begin{array}{l}\alpha \\
0.05299\end{array}$} & SSE \\
\hline & 19.607 & & & & & 0.5674 \\
\hline
\end{tabular}

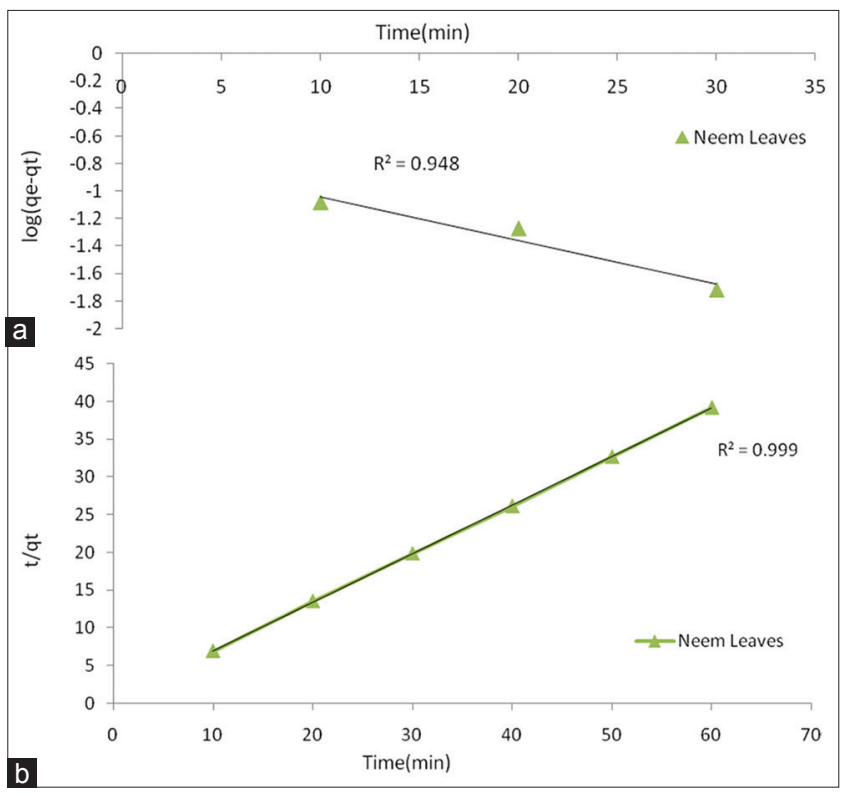

Fig. 2: (a) Kinetic modeling of adsorption of fluoride on neem leaves (Pseudo-first-order) (b) Kinetic modeling of adsorption of fluoride onto neem leaves (Pseudo-second-order)

The correlation coefficient $\left(\mathrm{R}^{2}\right)$ values for pseudo-second-order adsorption model have high values, i.e., 0.999 for the bioadsorbent neem leaves. The $\mathrm{R}^{2}$ value is higher than that of pseudo-first-order model. The lower SSE values for pseudo-second-order model also indicate that the adsorption kinetics of fluoride onto neem leaves can be better described by pseudo-second-order model. Similar trained has been observed by others for the adsorption of fluoride on many adsorbents [35-37].

\section{Intraparticle diffusion}

Rate of sorption is frequently used to analyze nature of the "ratecontrolling step" and the use of the intraparticle diffusion model has been greatly explored in this regard which is represented by the following Weber and Morris equation [33].

$\mathrm{q}_{\mathrm{t}}=\mathrm{k}_{\mathrm{ip}} \mathrm{t}^{0.5}+\mathrm{C}$

Where, kip is the intraparticle diffusion rate constant and C is the intercept, determined by the thickness of the boundary layer. According to this model, if adsorption of a solute is controlled by the intraparticle diffusion process, a plot of adsorption capacities (qt) versus $\mathrm{t}^{1 / 2}$ gives a straight line. Weber and Morris plots of $\mathrm{q}_{\mathrm{t}}$ versus $\mathrm{t}^{0.5}$ are shown in Fig. 3 for neem leaves. It is evident from the plots that there are two separate stages; first linear portion (Stage I) and second curved path followed by a plateau (Stage II). In Stage I, nearly $50 \%$ of fluoride was rapidly taken up by bioadsorbents within $5 \mathrm{~min}$. This is attributed to the immediate utilization of the most readily available adsorbing sites on the adsorbent surfaces. In Stage II, very slow diffusion of adsorbate from surface site into the inner pores is observed. Thus, the initial portion of fluoride adsorption by carbon adsorbents may be governed by the initial intraparticle transport of fluoride controlled by later part is controlled by pore diffusion and surface diffusion process. Similar dual nature with initial linear and then plateau was found in the literature [38].

Although intraparticle diffusion renders straight lines with correlation coefficient more than 0.9941 for the sorbents, the intercept of the line fails to pass through the origin in each case. This can be explained by the difference in the rate of mass transfer in the initial and final stages of adsorption [39] and indicates some degree of boundary layer control which implies that intraparticle diffusion is not the only rate controlling step [32]. The data were further used to learn about the slow step occurring in the present adsorption system using pore diffusion model.

\section{Bangham's model}

Bangham's model adsorption process is described by Bangham's model equation [40].

$$
\log \log \left(\frac{\mathrm{C}_{\mathrm{i}}}{\mathrm{C}_{\mathrm{i}}-\mathrm{q}_{\mathrm{t}} \cdot \mathrm{m}}\right)=\log \left(\frac{\mathrm{K}_{0} \cdot \mathrm{m}}{2 \cdot 303 \cdot \mathrm{V}}\right)+\alpha \cdot \log (\mathrm{t})
$$

Where,

$\mathrm{C}_{\mathrm{i}}=$ The initial concentration of the adsorbate in a solution $(\mathrm{mg} / \mathrm{L})$

$\mathrm{V}=$ Volume of solution in $(\mathrm{ml})$

$\mathrm{m}=$ Mass of the adsorbent $(\mathrm{g} / \mathrm{l})$

$\mathrm{q}_{\mathrm{t}}=$ The amount of adsorbate retained at time $\mathrm{t}(\mathrm{mg} / \mathrm{g})$

$\mathrm{K}_{0}=$ Constant

To plot $\log \log \left(\frac{C_{i}}{C_{i}-q_{t} \cdot m}\right)$ versus log t (Fig. 4) for neem leaves. The plot was found to be linear for adsorbent with correlation coefficient indicating that kinetics confirmed Bangham's equation, and therefore, the adsorption of fluoride onto neem leaves was pore diffusion controlled. Similar trend was found in the literature for the adsorption 


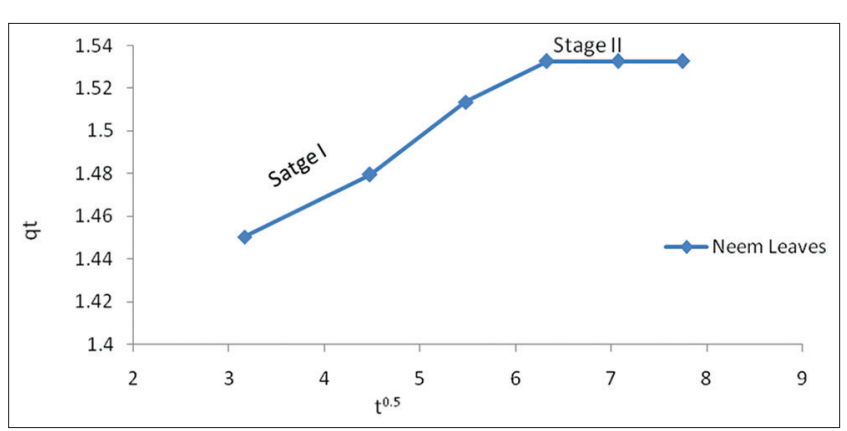

Fig. 3: Intraparticle diffusion plot neem leaves

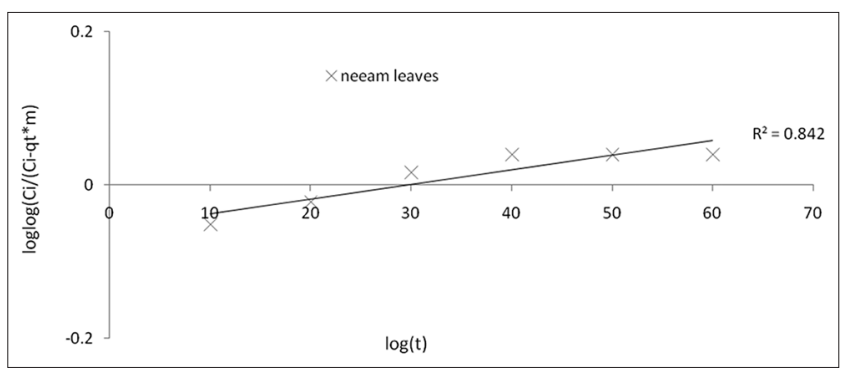

Fig. 4: Pour diffusion plot of neem leaves

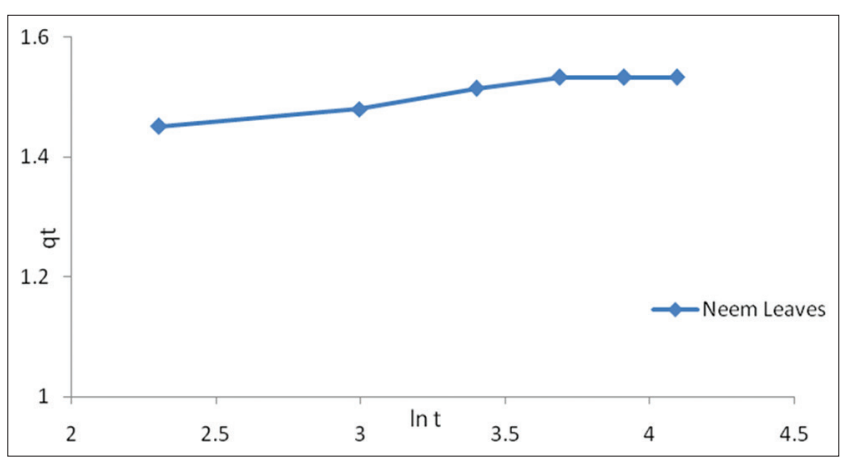

Fig. 5: Elovich equation plots of neem leaves

of fluoride onto waste carbon slurry.

\section{Elovich equation}

The Elovich equation [41]:

$$
\mathrm{q}_{\mathrm{t}}=\frac{\ln (\alpha \beta \mathrm{t})}{\beta}+\frac{\ln (\mathrm{t})}{\beta}
$$

Where,

$\alpha$ : Initial sorption rate $(\mathrm{mg} / \mathrm{g}$ min)

$\beta$ : Related to extent of surface coverage and activation energy for chemisorptions.

When $q_{t}$ versus $\ln (t)$ (Fig. 5) is plotted on a sheet of graph the result follows Elovich equation. Confirmation to this equation alone might be taken as evidence that the rate determining step is diffusion in nature [42]. Moreover, this equation should apply at conditions where desorption rate can be ignored [43]. The kinetic curve of sorption demonstrated good fitting with the model $\left(\mathrm{R}^{2}>0.9\right)$ which may indicate the diffusion rate limiting is more prominent in fluoride sorption by neem leaves.

\section{CONCLUSION}

By fitting of the kinetic data, the dynamics of sorption could be better described by pseudo-second-order model indicating a chemisorptive rate limiting for the adsorbents like neem leaves.

Although the plots of intraparticle diffusion render straight line with good correlation coefficient, the tail passes through origin in each case.

This suggests that the process is "complex" with more than one mechanism limiting the rate of sorption. The good fitting of the kinetics data to Elovich and Bangham's equation indicate that pore diffusion plays a key role in controlling the rate of reaction.

\section{REFERENCES}

1. Amini M, Mueller K, Abbaspour KC, Rosenberg T, Afyuni M, Møller KN, et al. Statistical modeling of global geogenic fluoride contamination in groundwaters. Environ Sci Technol 2008;42:3662-8.

2 WHO, editor. Guidelines for Drinking-Water Quality [Electronic Resource]: Incorporating First Addendum. Geneva: W.H.O.; 2006. p. 375-7.

3. Gaciri SJ, Davies TC. The occurrence and geochemistry of fluoride in some natural waters of Kenya. J Hydrol 1993;143:395-412.

4. Czarnowski W, Wrześniowska K, Krechniak J. Fluoride in drinking water and human urine in northern and central poland. Sci Total Environ 1996;191:177-84.

5. Azbar N, Turkman A. Defluorination in drinking waters. Water Sci Technol 2000;42:403-7.

6. Agarwal M, Rai K, Shrivastav R, Dass S. Deflouridation of water using amended clay. J Cleaner Prod 2003;11:439-44.

7. Ayoob S, Gupta AK. Fluoride in drinking water: A review on the status and stress effects. Crit Rev Environ Sci Technol 2006;36:433-87.

8. Wang LF, Huang JZ. Outline of control practice of endemic fluorosis in China. Soc Sci Med 1995;41:1191-5.

9. Mjengera H, Mkongo G. Appropriate deflouridation technology for use in flourotic areas in Tanzania. Phys Chem Earth 2003;28:1097-104.

10. Diaz-Barriga F, Navarro-Quezada A, Grijalva M, Grimaldo M, LoyolaRodriguez JP, Ortiz MD. Endemic fluorosis in Mexico. Fluoride 1997;30:233-9.

11. Kruse E, Ainchil J. Fluoride variations in groundwater of an area in Buenos Aires Province. Argent Environ Geol 2003;44:86-9.

12. WRC. Distribution of Fluoride-Rich Groundwater in Eastern and Mogwase Region of Northern and North-west province. WRC Report No. 526/1/01 1.1- 9.85. Pretoria; 2001.

13. Iwasaki AS, Tokimoto $T$, Kawasaki N, Nakamura $T$, Tanada $S$. Adsorption of fluoride ions onto carbonaceous materials. J Colloid Interface Sci 2004;275:35-9.

14. Banks D, Reimann C, Røyset O, Skarphagen H, Sæther OM. Natural concentrations of major and trace elements in some Norwegian bedrock groundwaters. Appl Geochem 1995;10:1-16.

15. Edmunds M, Smedley P. Fluoride in natural waters. In: Essentials of Medical Geology, Impacts of Natural Environment on Public Health. London, UK: Elsevier Academic Press; 2005.

16. Apambire WB, Boyle DR, Michel FA. Geochemistry, genesis, and health implications of fluoriferous groundwaters in the upper regions of Ghana. Environ Geochem 1997;33:13-24.

17. Reddy NB, Prasad KS. Pyroclastic fluoride in ground waters in some parts of Tadpatri Taluk, Anantapur district, Andhra Pradesh. Indian J Environ Health 2003;45:285-8.

18. Reardon EJ, Wang Y. A limestone reactor for fluoride removal from wastewaters. Environ Sci Technol 2000;34:3247-53.

19. Shen F, Chen X, Gao P, Chen G. Electrochemical removal of fluoride ions from industrial wastewater. Chem Eng Sci 2003;58:987-93.

20. WHO, editor. Guidelines for Drinking-Water Quality [Electronic Resource]: Incorporating First Addendum. Geneva: W.H.O.; 2006. p. 375-7.

21. Mahramanlioglu M, Kizilcikli I, Bicer IO. Adsorption of fluoride from aqueous solution by acid treated spent bleaching earth. J Fluorine Chem 2002;115;41-7.

22. Chinoy NJ. Effects of fluoride on physiology of animals and human beings. Indian J Environ Toxicol 1991;1:17-32.

23. Harrison PT. Fluoride in water: A UK perspective. J Fluorine Chem 2005; $126: 1448-56$

24. Fan X, Parker DJ, Smith MD. Adsorption kinetics of fluoride on low cost materials. Water Res 2003;37:4929-37. 
25. Zhou Y, Yu C, Shan Y. Adsorption of fluoride from aqueous solution on La3+ impregnated crosslinked gelatin. Sep Purif Technol 2004;36:89-94.

26. Islam M, Patel RK. Thermal activation of basic oxygen furnace slag and evaluation of its fluoride removal efficiency. Chem Eng J 2011;169:68-77.

27. Available from: http://www.fluoridealert.org/health.

28. Hichour M, Persin F, Sandeaux J, Gavach C. Fluoride removal from waters by donnan dialysis. Sep Purif Technol 2000;18:1-11.

29. APHA, AWWA, WWF. Standard Methods For the Examination of Water and Waste Water. Washington DC: APHA, AWWA, WWF; 1995.

30. APHA, AWWA, WWF Standard Methods For the Examination of Water and Waste Water. Washington DC: APHA, AWWA, WWF; 1995.

31. Viswanathan N, Sundaram CS, Meenakshi S. Removal of fluoride from. Aqueous solution using protonated chitosan beads. J Hazard Mater 2009;161:423-30

32. Meenakshi S, Viswanathan N. Identification of selective ion-exchange resin for fluoride sorption. J Colloid Interface Sci 2007;308:438-50

33. Ho YS, Ng JC, McKay G. Kinetics of pollutant sorption by biosorbents. Sep Purif Methods 2000;29:189-23.

34. Lagergran S, Venska KS. About the theory of so-called adsorbtion of soluble substances. Vetenskapsakad Handl 1898;24:1-39.
35. Weber WJ Jr., Morrisjc J. Kinetics of adsorption on carbon from solution. Sanit Eng Div 1963;89:31-59.

36. Simons R. Trace-element removal from ash dam waters by. Nano filtration and diffusion dialysis. Desalination 1993;89:325-41.

37. Sivasamy A, Singh KP, Mohan D, Maruthamuthu M. Studies on defluoridation of water by coal-based sorbents. J Chem Technol Biotechnol 2001;76:717-22.

38. Liao XP, Shi B. Adsorption of fluoride on zirconium (IV)-impregnated collagen fiber. Enviorn Sci Technol 2005;39:4628-32

39. Kumar E, Bhatnagar A, Ji M, Jung W, Lee SH, Kim SJ, et al. Defluoridation from aqueous solutions by granular ferric hydroxide (GFH). Water Res 2009;43:490-8.

40. Pandya KK, Prasad G, Singh VN. Mixed adsorbent for $\mathrm{Cu}(\mathrm{II})$ removal from aqueous solutions. Enviorn Technol Lett 1986;50:547-54.

41. Aharoni C, Ungarish M. Kinetics of activated chemisorption. Part 2.-Theoretical models. J Chem Soc Faraday Trans 1 1977;73:456-64.

42. Pavlatou A, Polyzopolus NA. Eur J Soil Sci 1988;39:425-36.

43. Rudzinksi W, Panczyk P. In: Schwarz JA, Contescu CI, editors. Surfaces of Nanoparticles and Porous Materials. New York: Dekker; 1998. p. 355. 